\title{
Implementasi Algoritma Wagner-Within pada Manajemen Inventori di PT X
}

\author{
Puspandam Katias, Achmad Affandi \\ Universitas Nahdlatul Ulama Surabaya \\ e-mail: puspandam@unusa.ac.id, achmad.affandu100@gmail.com
}

\begin{abstract}
The increasing competition in the manufacturing industry caused increasing inconsumer demand of the quality and quantity of a good product. Therefore, manufacturing companies must have reliable services, policies and product qualities to satisfy its customers. So it needs to be supported by efficient production system and inventory system. To able to create an efficient production system then need a good raw material inventory planning. This research aims to compere how efficiently in planning raw materials inventory between Wagner-Within Algorithm with the actual concept that applied to PT X, Sidoario. The methodology of this research is qualitative descriptive research. The findings this research is engaged in packaging (woven bag and jumbo bag) with main raw materials such as plastic ore and supporting material in inner, thread, additive, and pigment. Based on the result of the analysis is known that the actual concept of the company gives the total inventory cost IDR 3.151.000.000 with the frequency of ordering 12 times while WagnerWithin Algorithm method provides a more efficient total inventory cost of Rp. 2.685.821.101 with 8 times the frequency of ordering and can savings of $14.8 \%$ of total raw material inventory cost.
\end{abstract}

Keywords: wagner-within algorithm, lot sizing, inventory management

\section{PENDAHULUAN}

\subsection{Latar Belakang}

Dengan semakin berkembangnya teknologi dan dunia industri manufaktur saat ini memacu pertumbuhan industri manufaktur, yang menyebabkan meningkatkannya persaingan di antara perusahaan-perusahaan manufaktur untuk memperebutkan konsumen sehingga mengakibatkan meningkatnya pula tuntutan konsumen terhadap kualitas dan kuantitas yang baik dari suatu produk. Selain itu, perusahaan manufaktur juga dituntut untuk dapat memuaskan konsumen dengan cara menyelesaikan pesanan konsumen tepat pada waktu yang diharapkan oleh para konsumen Oleh karena itu, perusahaan manufaktur haruslah mempunyai pelayanan, kebijakan, dan kualitas produk yang dapat diandalkan guna memuaskan konsumennya. Sehingga perlu ditunjang oleh suatu sistem produksi dan sistem persediaan yang seefisien mungkin. Untuk dapat menciptakan sistem produksi yang efisien maka diperlukan suatu perencanaan produksi yang baik.

Persediaan adalah persediaan barang atau sumber yang digunakan dalam suatu organisasi. Sedangkan menurut (Yamit, 2005) persediaan merupakan kekayaan perusahaan yang memiliki peranan penting dalam operasi bisnis, sehingga perusahaan perlu melakukan manajemen persediaan proaktif, artinya perusahaan harus mampu mengantisipasi keadaan maupun tantangan yang ada dalam manajemen persediaan untuk mencapai sasaran akhir, yaitu untuk meminimalisasi total biaya yang harus dikeluarkan oleh perusahaan untuk penanganan persediaan.

Dalam upaya meningkatkan daya saing dan profitabilitas, seperti yang dikemukakan Rangkuti (2007) bahwa keuntungan yang maksimum salah satunya dapat dicapai dengan meminimumkan 
biaya yang berkaitan dengan persediaan, sangat diperlukan perencanaan persediaan yang baik, efektif, dan efisien khususnya untuk persediaan bahan mentah atau bahan baku, mengingat bahwa bahan baku dalam perusahaan manufaktur merupakan faktor yang sangat berpengaruh terhadap kelancaran bisnis.

Selama ini perusahaan manufaktur pada umumnya melakukan perencanaan dan pengendalian tidak berdasarkan metode-metode yang sudah baku, tetapi hanya berdasarkan pada pengalaman-pengalaman sebelumnya. Hal tersebut sering menyebabkan terjadinya kelebihan atau penumpukan bahan baku maupun kekurangannya yang menyebabkan pembengkakan biaya, di samping terjadi kekurangan-kekurangan yang dapat mengganggu atau menghambat proses produksi dalam memenuhi permintaan konsumen.

Untuk mengatasi permasalahan dalam persediaan suatu perusahaan, terdapat beberapa metode yang dapat diterapkan dalam rangka meningkatkan efisiensi manajemen persediaan. Salah satunya metode lot sizing di mana ukuran jumlah barang yang dipesan akan berhubungan dengan biaya pemesanan (set-up). Lot sizing menurut Rangkuti (2007) adalah teknik dalam meminimalkan jumlah barang yang akan dipesan, sehingga dapat meminimalkan total biaya persediaan. Salah satu pendekatan lot sizing yang paling tepat yang dapat meminimalkan biaya total persediaan yakni Algoritma Wagner Within (AWW). Algoritma ini dikembangkan oleh Wagner dan Within pada tahun 1958 untuk memberikan solusi optimum bagi persoalan ukuran pemesanan deterministik pada suatu kurun waktu tertentu di mana kebutuhan seluruh periode harus terpenuhi. Menurut jurnal penelitian (Rajhans dan Kulkarnia, 2013:807) Algoritma Wagner Within adalah metode yang akurat untuk menentukan ukuran yang optimal untuk suatu produk dengan permintaan dinamis dengan produksi satu tahap tanpa mempertimbangkan batasan kapasitas. Model Algoritma Wagner-Whitin menghasilkan biaya yang optimal walaupun biaya tetap bervariasi dari satu periode ke periode lainnya.

Penelitian ini dilakukan di salah satu perusahaan yang bergerak pada bidang kemasan/packaging di PT X yang beroperasi sejak tahun 1981, perusahaan ini memproduksi karung plastik dan aksesorisnya. Produk yang dihasilkan oleh PT X adalah woven bag dan jumbo bag. Baik woven bag dan jumbo bag dihasilkan melalui proses perajutan raw material, penjahitan, dan printing. Produk woven bag biasanya digunakan sebagai pembungkus pupuk, semen, tepung, beras, dll., sedangkan produk jumbo bag biasanya digunakan sebagai pembungkus dalam ukuran yang sangat besar seperti barang-barang yang dikirim dengan kontainer.

Dalam proses produksinya, PT X memiliki permasalahan pada persediaan salah satu bahan bakunya yakni bijih plastik. Bahan baku bijih plastik merupakan bahan baku yang dibutuhkan untuk pembuatan woven bag maupun jumbo bag. Bijih plastik ini langsung diimpor langsung dari negara lain, hal ini membutuhkan waktu tunggu yang lumayan lama untuk proses pemesanan bahan baku. Berkaitan dengan lamanya waktu pemesanan bahan baku produk-produk tersebut, perusahaan ini harus mempunyai strategi yang tepat dalam merencanakan persediaan bahan baku agar perusahaan dapat mengelola produksi secara efektif dan efisien.

Berdasarkan pertimbangan dari latar belakang yang telah dijelaskan tersebut, maka penulis tertarik untuk mengadakan penelitian tentang persediaan bahan baku dan cara meminimalkan total biaya persediaan menggunakan metode Algoritma Wagner-Within (AWW). 


\subsection{Rumusan Masalah}

Berdasarkan apa saja yang telah dituliskan pada latar belakang di atas, penulis dapat mengidentifikasikan permasalahan dalam perencanaan persediaan bahan baku yang berhubungan langsung dengan produksi perusahaan.

Apakah metode Algoritma Wagner-Within (AWW) dalam analisis persediaan bahan baku dapat berjalan secara efisien berdasarkan tolak ukur total biaya persediaan bahan baku dibandingkan dengan kondisi existing yang diterapkan PT X, Sidoarjo?

\subsection{Tujuan Penelitian}

Adapun tujuan yang ingin dicapai dalam rangka penelitian ini secara garis besar adalah sebagai berikut.

Untuk membandingkan seberapa efisien berdasarkan tolak ukur total biaya persediaan bahan baku dalam analisis persediaan bahan baku antara metode Algoritma Wagner-Within (AWW) dengan kondisi existing yang diterapkan pada PT X, Sidoarjo.

\section{LANDASAN TEORI}

\subsection{Persediaan}

Sedangkan menurut Hendra (2009:131) persediaan didefinisikan sebagai barang yang disimpan untuk digunakan untuk dijual pada periode mendatang. Persediaan dapat berbentuk bahan baku yang disimpan untuk diproses, komponen yang diproses, barang dalam proses pada proses manufaktur, dan barang jadi yang disimpan untuk dijual.

Pada dasarnya, persediaan merupakan suatu hal yang sangat penting bagi perusahaan khususnya perusahaan manufaktur yang sehari- hari melakukan proses produksi, baik memproduksi barang maupun jasa untuk menunjang kelancaran proses produksinya.

\subsection{Biaya Akibat Persediaan}

Menurut Tampubolon (2004:194), biayabiaya yang sering muncul akibat persediaan adalah sebagai berikut.

1. Biaya penyimpanan

Biaya penyimpanan merupakan biaya yang timbul di dalam menyimpan persediaan, di dalam usaha mengamankan persediaan dari kerusakan, keusangan dan keausan, dan kehilangan. Biaya penyimpanan per periode akan semakin besar apabila kuantitas bahan yang dipesan semakin banyak atau rata-rata persediaan semakin tinggi (Rasjidin, dkk., 2007: 157) yang meliputi beberapa hal berikut.

- Biaya fasilitas penyimpanan (penerangan, pendinginan dan pemanasan)

- Biaya modal

- Biaya keusangan dan keausan (amortization)

- Biaya asuransi persediaan

- Biaya perhitungan fisik dan konsolidasi laporan

- Biaya kehilangan barang (pencurian, perusakan, perampokan)

- Biaya penanganan Persediaan (handling cost)

- Biaya pajak persediaan

2. Biaya pemesanan

Biaya pemesanan pada umumnya (di luar biaya bahan dan potongan kuantitas) tidak naik apabila kuantitas pemesanan bertambah besar. Namun, apabila semakin banyak komponen yang dipesan setiap kali pesan, jumlah pesanan per periode turun, maka biaya pemesanan total akan turun. Berikut adalah biaya-biaya yang termasuk biaya pemesanan. 
- Biaya angkut

- Biaya upah

- Biaya telepon

- Biaya surat menyurat. dan

- Biaya pemeriksaan penerimaan (raw material inspection)

3. Biaya persiapan

Biaya persiapan merupakan biaya-biaya yang timbul di dalam menyiapkan mesin dan peralatan untuk dipergunakan dalam proses konversi seperti:

- Biaya mesin yang menganggur (idle capacity)

- Biaya Penyiapan tenaga kerja

- Biaya Penjadwalan (scheduling)

4. Biaya kehabisan stock (stock out cost)

Biaya tersebut disebut juga dengan biaya kekurangan atau kehabisan bahan. Biaya ini timbul akibat persediaan yang tidak mencukupi permintaan. Perusahaan sulit mengukur biaya kekurangan atau kehabisan pada praktiknya terutama karena biaya ini sering merupakan opportunity cost yang sulit diperkirakan secara objektif. Biaya-biaya yang termasuk biaya kekurangan atau kehabisan bahan adalah:

- Biaya kehilangan penjualan

- Biaya kehilangan langganan

- Biaya Pemesanan khusus

- Biaya ekspedisi

- Selisih harga

- Biaya yang timbul akibat terganggunya operasi

- Biaya tambahan, pengeluaran manajerial.

\subsection{Manajemen Persediaan}

Dalam menjalankan operasional perusahaan khususnya perusahaan manufaktur maka tidak akan terlepas dari kegiatan penting dalam melakukan persediaan yaitu manajemen persediaan. Menurut Assauri (2004:176) mengemukakan bahwa perusahaan haruslah dapat mempertahankan suatu jumlah persediaan yang optimum yang dapat menjamin kebutuhan bagi kelancaran kegiatan perusahaan dalam jumlah dan mutu yang tepat serta dengan biaya yang serendah-rendahnya. Berdasarkan pernyataan tersebut Baroto (2002:54) menegaskan yang dimaksud kriteria optimum adalah meminimalisasi biaya total yang terkait dengan persediaan, yaitu biaya penyimpanan dan pemesanan. Tingkat persediaan yang optimum dapat diatur dengan memenuhi kebutuhan bahan-bahan dalam jumlah, mutu, dan waktu yang tepat serta jumlah biaya yang rendah.

\subsection{Prasyarat Manajemen Persediaan yang Efektif dan Efisien}

Sumayang (2003) menjelaskan dalam pengolahan persediaan terdapat pertimbangan-pertimbangan yang merupakan dasar pemikiran inventory management, di antara lain sebagai berikut.

1. Struktur biaya persediaan
a. Biaya per unit (item cost)
b. Biaya penyiapan pemesanan (ordering cost)
c. Biaya pengelolaan persediaan (carrying cost)
d. Biaya risiko kerusakan (cost of obsoles- cence)
e. Biaya akibat kehabisan persediaan (stock out cost)

2. Penentuan seberapa besar dan kapan pemesanan harus dilakukan. Hal ini sangat dipengaruhi oleh ketergantungan permintaan terhadap kondisi pasar.
a. Independent demand inventory
Pada kondisi ini, persediaan sangat ber- gantung pada permintaan pasar. Pende- katan yang tepat adalah pengisian kembali persediaan disesuaikan dengan jumlah yang digunakan atau merupakan penggan- 
tian (replenishment). Pada saat persediaan mulai berkurang, maka perusahaan dipicu untuk segera melakukan pemesanan sebagai pengganti persediaan yang telah digunakan.

b. Dependent demand inventory

Pemesanan tidak dilakukan apabila persediaan berkurang. Pada kondisi ini, pemesanan dilakukan bila ada permintaan barang dari tahapan proses berikutnya.

\subsection{Lot Sizing}

Lot Sizing merupakan teknik penentuan ukuran tumpuk atau jumlah barang atau bahan yang dipesan pada setiap pemesanan (Pardede, 2004: 495). Menurut Rangkuti (2007) lot sizing merupakan teknik dalam meminimalkan jumlah barang yang akan dipesan sehingga dapat meminimalkan total biaya persediaan. Menurut Herjanto (1999: 270) semakin rendah ukuran lot yang berarti semakin sering melakukan pemesanan barang akan menurunkan biaya penyimpanan, tetapi menambah biaya pemesanan. Sebaliknya, semakin tinggi ukuran lot akan mengurangi frekuensi pemesanan yang berarti mengurangi biaya pemesanan, tetapi mengakibatkan meningkatnya biaya penyimpanan. Untuk itu, perlu dicari ukuran lot yang tepat yang dapat meminimalkan biaya total persediaan.

Beberapa teknik lot sizing dengan tujuan meminimalkan jumlah biaya persediaan menurut Rajhans dan Kulkarnia (2013:806):

1. Lot for Lot (LFL)

2. Economic order Quantity (EOQ)

3. Period order quantity (POQ)

4. Least unit cost

5. Least total cost

6. Least period cost

7. Wagner-Whitin Algorithm/Algoritma WagnerWithin.

\subsection{Algoritma Wagner-Within}

Algoritma ini dikembangkan oleh Wagner dan Within pada tahun 1958 untuk memberikan solusi optimum bagi persoalan ukuran pemesanan deterministik pada suatu kurun waktu tertentu dimana kebutuhan seluruh periode harus terpenuhi. Algoritma Wagner Within adalah metode yang akurat untuk menentukan ukuran yang optimal untuk suatu produk dengan permintaan dinamis dengan produksi satu tahap tanpa mempertimbangkan batasan kapasitas (Rajhans dan Kulkarnia, 2013:807). Metode Algoritma WagnerWhitin menghasilkan total biaya persediaan bahan baku yang optimal walaupun biaya tetap bervariasi dari satu periode ke periode lainnya. Metode ini melakukan minimasi penggabungan biaya total persediaan bahan baku dari setup cost dan holding cost tersebut dengan hasil mendekati nilai yang sama untuk jumlah pemesanan yang dilakukan. Wagner dan Within (2004) menjabarkan langkah-langkah AWW sebagai berikut.

\section{Langkah 1}

Hitung biaya total persediaan (biaya pesan dan biaya simpan), selanjutnya didefinisikan Oen. Rumusan Oen tersebut dinyatakan sebagai berikut.

oen $=\mathbf{A}+\boldsymbol{h} \Sigma($ qen - qet $)$ nt $=e$

untuk $1 \leq \mathrm{e} \leq \mathrm{n} \leq \mathrm{N}$

Di mana:

Oen : Biaya total persediaan (Rp)

$A \quad$ : Biaya pesan (Rp/pesan)

$h$ : Biaya simpan per unit per periode $(\mathrm{Rp} /$ unit/periode)

qet $: \Sigma=D t$

$D t$ : Permintaan pada periode $t$

$e \quad$ : Batas awal periode yang dicakup pada pemesanan qet

$n \quad:$ Batas maksimum periode yang dicakup pada pemesanan qet 


\section{Langkah 2}

Nilai $f n$ adalah nilai Biaya total dan pemesanan optimal yang dihitung dengan menggunakan formula sebagai berikut.

$f n=\operatorname{Min}[$ Oen $+f e-1]$

untuk e $=1,2, ., \mathrm{n}$ dan $\mathrm{n}=1,2, ., \mathrm{N}$

\section{Langkah 3}

Solusi optimal $f t$ diperoleh dari perhitungan rekursif mundur seperti berikut:

- $\mathrm{fN}=$ Oen $+\mathrm{f}$ e-1

Pemesanan-terakhir dilakukan pada periode $e$ untuk memenuhi permintaan dari periode $e$ sampai periode $N$

- $\mathrm{fe}-1=$ Ove- $1+\mathrm{fv}_{\mathrm{v}}-1$
Pemesanan sebelum pemesanan-terakhir harus dilakukan pada periode $v$ untuk memenuhi permintaan dari periode $v$ sampai periode $e-1$.

- $\mathbf{f u}-\mathbf{1}=\mathrm{Ou}-\mathbf{1}+\mathrm{f} 0$

Pemesanan yang pertama harus dilakukan pada periode 1 untuk memenuhi permintaan dari periode 1 sampai periode $u$ - 1 .

Alasan dari penggunaan teknik ini adalah karena teknik ini menghasilkan total biaya yang paling minimum karena menggunakan program dinamis dan pendekatan matematisnya yang sangat detail. Tujuan teknik ini adalah untuk mendapatkan strategi pemesanan yang optimal untuk seluruh jadwal kebutuhan bersih dengan jalan meminimalisasi total ongkos pengadaan dan ongkos simpan (Maulana dan Setyorini, 2012:4).

\subsection{Model Penelitian}

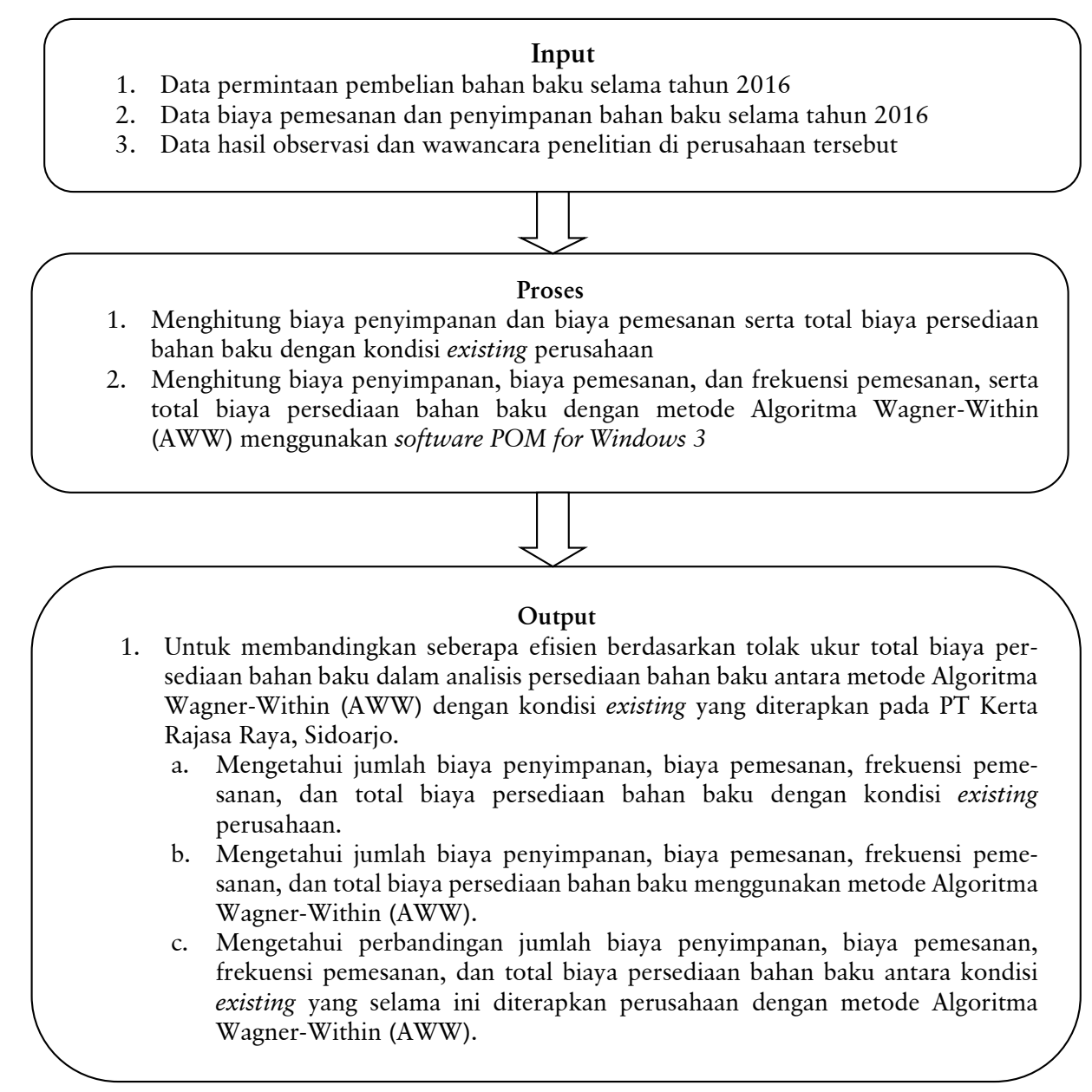




\section{METODE PENELITIAN}

Pendekatan yang digunakan di dalam penelitian ini adalah pendekatan Kualitatif dengan metode Studi Kasus Deskriptif. Menurut Sugiyono (2010:14), metode penelitian kualitatif adalah metode penelitian yang berlandaskan pada filsafat postpositivisme, digunakan untuk meneliti objek yang alamiah, (sebagai lawannya adalah eksperimen) di mana peneliti adalah sebagai instrumen kunci, pengambilan sampel sumber data dilakukan secara purposive dan snowball, teknik pengumpulan dengan trianggulasi (gabungan).

\subsection{Prosedur Pengumpulan Data}

Terdapat data yang dikumpulkan dalam penelitian ini berdasarkan jenis dan sumbernya. Sumber data berupa data primer dan sekunder, data primer didapat pada saat berada di lapangan melalui observasi/pengamatan secara langsung yang dilakukan dengan cara mengamati kondisi yang terjadi pada perusahaan tersebut dan mengetahui langsung tentang proses persediaan bahan baku dan interview/wawancara secara langsung di PT X, Sidoarjo, sedangkan data sekunder menggunakan beberapa data sekunder sebagai literatur buku, jurnal maupun penelitian yang telah dilakukan sebelumnya. Di samping itu, data sekunder dalam penelitian ini adalah data persediaan bahan baku tahun 2016, meliputi jumlah persediaan, awal, jumlah pemakaian, jumlah pesanan atau pembelian bahan baku, serta komponen-komponen biaya pemesanan (holding cost) dan biaya penyimpanan (ordering cost).

\subsection{Teknis Analisis}

Pada teknik analisis yang digunakan dalam penelitian ini adalah dengan cara menghitung bagaimana jumlah dan frekuensi pembelian, serta biaya-biaya persediaan (Holding Cost, Ordering Cost dan Total Inventory Cost) menurut konsep aktual perusahaan dan menurut perhitungan metode Algoritma Wagner-Within (AWW) dengan menggunakan software POM for Windows 3, serta melakukan perbandingan biaya persediaan bahan baku menurut konsep aktual dalam perusahaan dan biaya persediaan bahan baku menggunakan metode Algoritma Wagner-Within (AWW).

Berikut ini merupakan teknik analisis data yang digunakan oleh peneliti dalam melakukan penelitian ini, yaitu:

a. Kondisi existing perusahaan

b. Algoritma Wagner-Within (AWW)

Untuk menentukan biaya terkecil yang ditimbulkan dari perhitungan lot sizing yang telah dilakukan, maka terdapat 4 tahap dalam menganalisis dan membandingkan total biaya persediaan bahan baku berdasarkan perhitungan konsep aktual perusahaan dan metode Algoritma Wagner-Within (AWW) yaitu:

Tahap 1: Menentukan biaya pemesanan dengan rumus:

Biaya Pemesanan $=\Sigma$ pesanan $\mathrm{x}$ biaya $/$ sekali pesan

Tahap 2: Menentukan biaya penyimpanan dengan rumus:

Biaya Penyimpanan $=\Sigma$ inventori $\mathrm{x}$ biaya simpan/unit/bulan

Tahap 3: Menentukan total biaya persediaan bahan baku keseluruhan dengan rumus:

Total Biaya persediaan bahan baku = Biaya Pemesanan + Biaya Penyimpanan

Tahap 4 Perbandingan total biaya persediaan bahan baku konsep aktual perusahaan dengan metode Algoritma Wagner-Within (AWW)

Dalam melakukan perhitungan biaya persediaan tiap bahan baku dengan menggunakan 
metode Algoritma Wagner-Within (AWW) melalui software POM for Windows 3.

\section{HASIL DAN PEMBAHASAN}

\subsection{Deskripsi Hasil Penelitian}

\subsubsection{Perhitungan Menurut Kondisi Existing Perusahaan}

Pencatatan jumlah persediaan bahan baku yang datang dan dipakai dilakukan setiap hari kerja di PT X. Tabel 1 menyajikan informasi mengenai pembelian bahan baku perusahaan tiap bulannya pada tahun 2016 .

Tabel 1 Pembelian Bahan Baku Tahun 2016 Kondisi Existing PT X

\begin{tabular}{|c|c|c|c|c|c|c|}
\hline \multirow{2}{*}{ Bulan } & \multicolumn{7}{|c|}{ Pembelian Bahan Baku (Ton) } \\
\cline { 2 - 7 } & $\begin{array}{c}\text { Bijih } \\
\text { Plastik }\end{array}$ & Inner & $\begin{array}{c}\text { Benang } \\
\text { Jahit }\end{array}$ & Additive & Pigmen & Total \\
\hline Jan & 794 & 35 & 26 & 18 & 9 & 882 \\
\hline Feb & 1.071 & 48 & 36 & 24 & 12 & 1.190 \\
\hline Mar & 871 & 39 & 29 & 19 & 10 & 968 \\
\hline Apr & 852 & 38 & 28 & 19 & 9 & 947 \\
\hline Mei & 749 & 33 & 25 & 17 & 8 & 832 \\
\hline Juni & 1.011 & 45 & 34 & 22 & 11 & 1.124 \\
\hline Juli & 666 & 30 & 22 & 15 & 7 & 740 \\
\hline Agust & 876 & 39 & 29 & 19 & 10 & 973 \\
\hline Sept & 611 & 27 & 20 & 14 & 7 & 679 \\
\hline Okt & 1.532 & 68 & 51 & 34 & 17 & 1.703 \\
\hline Nov & 610 & 27 & 20 & 14 & 7 & 678 \\
\hline Des & 778 & 35 & 26 & 17 & 9 & 864 \\
\hline Total & 10.420 & 463 & 347 & 232 & 116 & 11.578 \\
\hline
\end{tabular}

Sumber: Data Internal Perusahaan Diolah

Untuk Biaya pemesanan bahan baku adalah biaya yang dikeluarkan oleh perusahaan PT X, berkenaan dengan dilakukannya pembelian bahan baku yang tidak dipengaruhi oleh kuantitas bahan baku yang dipesan. Bahan baku PT X di impor langsung dari Singapura, Arab Saudi, dan Amerika Serikat. Biaya pemesanan bahan baku perusahaan PT X pada tahun 2016 secara rinci terdapat dalam Tabel 2 sebagai berikut.
Tabel 2 Biaya Pemesanan Bahan Baku Tahun 2016 Kondisi Existing PT X

\begin{tabular}{|c|c|c|c|c|c|c|}
\hline \multirow{2}{*}{ Bulan } & \multicolumn{5}{|c|}{ Biaya Pemesanan (Rp) } & \multirow{2}{*}{$\begin{array}{l}\text { Total Biaya } \\
\text { Pemesanan } \\
\text { (Rp) }\end{array}$} \\
\hline & $\begin{array}{c}\text { Bijih Plastik } \\
(\mathrm{Rp})\end{array}$ & Inner (Rp) & \begin{tabular}{|c|}
$\begin{array}{c}\text { Benang Jahit } \\
(\mathrm{Rp})\end{array}$ \\
\end{tabular} & $\begin{array}{c}\begin{array}{c}\text { Additive } \\
\text { (Rp) }\end{array} \\
\end{array}$ & $\begin{array}{c}\text { Pigmen } \\
(\mathrm{Rp})\end{array}$ & \\
\hline Jan & 159.300 .000 & 7.080 .000 & 5.310 .000 & 3.540 .000 & 1.770 .000 & 177.000 .000 \\
\hline Feb & 216.000 .000 & 9.600 .000 & 7.200 .000 & 4.800 .000 & 2.400 .000 & 240.000 .000 \\
\hline Mar & 223.200 .000 & 9.920 .000 & 7.440 .000 & 4.960 .000 & 2.480 .000 & 248.000 .000 \\
\hline Apr & 252.000 .000 & 11.200 .000 & 8.400 .000 & 5.600 .000 & 2.800 .000 & 280.000 .000 \\
\hline Mei & 140.400 .000 & 6.240 .000 & 4.680 .000 & 3.120 .000 & 1.560 .000 & 156.000 .000 \\
\hline Juni & 243.900 .000 & 10.840 .000 & 8.130 .000 & 5.420 .000 & 2.710 .000 & 271.000 .000 \\
\hline Juli & 146.700 .000 & 6.520 .000 & 4.890 .000 & 3.260 .000 & 1.630 .000 & 163.000 .000 \\
\hline Agust & 219.600 .000 & 9.760 .000 & 7.320 .000 & 4.880 .000 & 2.440 .000 & 244.000 .000 \\
\hline Sept & 212.400 .000 & 9.440 .000 & 7.080 .000 & 4.720 .000 & 2.360 .000 & 236.000 .000 \\
\hline Okt & 377.100 .000 & 16.760 .000 & 12.570 .000 & 8.380 .000 & 4.190 .000 & 419.000 .000 \\
\hline Nov & 241.200 .000 & 10.720 .000 & 8.040 .000 & 5.360 .000 & 2.680 .000 & 268.000 .000 \\
\hline Des & 181.800 .000 & 8.080 .000 & 6.060 .000 & 4.040 .000 & 2.020 .000 & 202.000 .000 \\
\hline Total & 2.613 .600 .000 & 116.160 .000 & 87.120 .000 & 58.080 .000 & 29.040 .000 & 2.904 .000 .000 \\
\hline
\end{tabular}

Sumber: Data Internal Perusahaan Diolah

Untuk Biaya penyimpanan bahan baku PT $\mathrm{X}$ yang ditunjukkan dalam Tabel 3 merupakan biaya penyimpanan bahan baku utama (bijih plastik) maupun bahan baku pendukung (inner, benang jahit, additive, pigmen) selama bulan Januari sampai bulan Desember tahun 2016. Biaya tersebut terdiri dari biaya fasilitas penyimpanan (listrik, dll.), biaya asuransi persediaan, biaya penanganan persediaan, dll. Biaya penyimpanan bahan baku perusahaan PT X pada tahun 2016 secara rinci terdapat dalam Tabel 3.

Tabel 3

Biaya Penyimpanan Bahan Baku Tahun 2016 Kondisi Existing PT X

\begin{tabular}{|c|c|c|c|c|c|c|}
\hline \multirow[b]{2}{*}{ Bulan } & \multicolumn{5}{|c|}{ Biaya Penyimpanan (Rp) } & \multirow{2}{*}{$\begin{array}{c}\text { Total Biaya } \\
\text { Penyimpanan } \\
\text { (Rp) } \\
\end{array}$} \\
\hline & $\begin{array}{c}\text { Bijih Plastik } \\
\text { (Rp) }\end{array}$ & $\begin{array}{c}\begin{array}{l}\text { Inner } \\
(\mathrm{Rp})\end{array} \\
\end{array}$ & $\begin{array}{c}\text { Benang } \\
\text { Jahit (Rp) }\end{array}$ & $\begin{array}{c}\text { Additive } \\
\text { (Rp) }\end{array}$ & Pigmen (Rp) & \\
\hline Jan & 12.600 .000 & 560.000 & 420.000 & 280.000 & 140.000 & 14.000 .000 \\
\hline Feb & 14.400 .000 & 640.000 & 480.000 & 320.000 & 160.000 & 16.000 .000 \\
\hline Mar & 17.100 .000 & 760.000 & 570.000 & 380.000 & 190.000 & 19.000 .000 \\
\hline Apr & 20.700 .000 & 920.000 & 690.000 & 460.000 & 230.000 & 23.000 .000 \\
\hline Mei & 15.300 .000 & 680.000 & 510.000 & 340.000 & 170.000 & 17.000 .000 \\
\hline Juni & 25.200 .000 & 1.120 .000 & 840.000 & 560.000 & 280.000 & 28.000 .000 \\
\hline Juli & 18.900 .000 & 840.000 & 630.000 & 420.000 & 210.000 & 21.000 .000 \\
\hline Agust & 18.900 .000 & 840.000 & 630.000 & 420.000 & 210.000 & 21.000 .000 \\
\hline Sept & 18.900 .000 & 840.000 & 630.000 & 420.000 & 210.000 & 21.000 .000 \\
\hline Okt & 23.400 .000 & 1.040 .000 & 780.000 & 520.000 & 260.000 & 26.000 .000 \\
\hline Nov & 16.200 .000 & 720.000 & 540.000 & 360.000 & 180.000 & 18.000 .000 \\
\hline Des & 20.700 .000 & 920.000 & 690.000 & 460.000 & 230.000 & 23.000 .000 \\
\hline Total & 222.300 .000 & 9.880 .000 & 7.410 .000 & 4.940 .000 & 2.470 .000 & 247.000 .000 \\
\hline
\end{tabular}

Sumber: Data Internal Perusahaan Diolah 
Total biaya persediaan bahan baku per tahun dengan konsep aktual yang diterapkan perusahaan adalah penjumlahan dari total biaya pemesanan per tahun dan total biaya penyimpanan per tahun. Total biaya pemesanan diperoleh dari perhitungan total biaya angkut/biaya transportasi, biaya administrasi dan biaya komunikasi. Lalu, total biaya penyimpanan per tahun didapat dari total biaya fasilitas penyimpanan (listrik, dll.), biaya asuransi persediaan, biaya penanganan persediaan.

Berikut adalah total biaya persediaan tiap bahan baku tahun 2016 menggunakan kondisi existing yang digunakan perusahaan dapat dilihat pada Tabel 4.

Tabel 4 Total Biaya Persediaan Tiap Bahan Baku Tahun 2016 Kondisi Existing PT X

\begin{tabular}{|c|c|c|c|c|c|}
\hline \multicolumn{5}{|c|}{ Total Biaya Persediaan Tiap Bahan Baku (Rp) } & \multirow{2}{*}{$\begin{array}{c}\text { Total Biaya } \\
\text { Persediaan } \\
\text { Bahan Baku } \\
\text { (Rp) }\end{array}$} \\
\hline $\begin{array}{l}\text { Bijih Plastik } \\
\text { (Rp) }\end{array}$ & Inner (Rp) & $\begin{array}{c}\text { Benang } \\
\text { Jahit (Rp) }\end{array}$ & $\begin{array}{l}\text { Additive } \\
\text { (Rp) }\end{array}$ & $\begin{array}{l}\text { Pigmen } \\
\text { (Rp) }\end{array}$ & \\
\hline 2.835 .900 .000 & 126.040 .000 & 94.530 .000 & 63.020 .000 & 31.510 .000 & 3.151 .000 .000 \\
\hline
\end{tabular}

Sumber: Data Internal Perusahaan Diolah

Perhitungan total biaya persediaan bahan baku per tahun terdapat pada Tabel 5 berikut.

Tabel 5

Hasil Perhitungan Total Biaya Persediaan Tahun 2016 Kondisi Existing PT X

\begin{tabular}{|c|c|c|}
\hline $\begin{array}{c}\text { Biaya } \\
\text { Pemesanan (Rp) }\end{array}$ & $\begin{array}{c}\text { Biaya } \\
\text { Penyimpanan } \\
(\mathrm{Rp})\end{array}$ & $\begin{array}{c}\text { Total Biaya } \\
\text { Persediaan } \\
(\mathrm{Rp})\end{array}$ \\
\hline 2.904 .000 .000 & 247.000 .000 & 3.151 .000 .000 \\
\hline
\end{tabular}

Sumber: Data Internal Perusahaan Diolah

Total biaya persediaan PT X dengan kondisi existing yang selama ini diterapkan perusahaan pada tahun 2016 sebesar Rp 3.151.000.000, dengan biaya pemesanan sebesar Rp 2.904.000.000 dan biaya penyimpanan sebesar Rp 247.000.000.

\subsubsection{Perhitungan menurut Metode Algoritma Wagner-Within (AWW)}

Berikut Perhitungan kuantitas dan frekuensi pemesanan tiap bahan baku secara rinci pada tahun 2016 dengan metode Algoritma WagnerWithin (AWW) menggunakan software POM for Windows 3 dapat dilihat pada Tabel 6 .

Tabel 6 Perhitungan Kuantitas dan Frekuensi Pemesanan Tiap Bahan Baku Tahun 2016 (Metode Algoritma Wagner-Within)

\begin{tabular}{|l|c|c|r|r|r|}
\hline $\begin{array}{c}\text { Nama } \\
\text { Bahan } \\
\text { Baku }\end{array}$ & $\begin{array}{c}\text { Permintaan } \\
\text { Pembelian } \\
\text { (Ton) }\end{array}$ & $\begin{array}{c}\text { Frekuensi } \\
\text { Pemesanan }\end{array}$ & $\begin{array}{c}\text { Biaya } \\
\text { Pemesanan/ } \\
\text { Pesan (Rp) }\end{array}$ & $\begin{array}{c}\text { Biaya } \\
\text { Penyimpanan/ } \\
\text { Ton (Rp) }\end{array}$ & $\begin{array}{c}\text { Total Biaya } \\
\text { Persediaan } \\
\text { (Rp) }\end{array}$ \\
\hline $\begin{array}{l}\text { Bijih } \\
\text { Plastik }\end{array}$ & 10.421 & $8 \mathrm{kali}$ & 1.742 .400 .000 & 674.813 .400 & 2.417 .213 .400 \\
\hline Inner & 464 & $8 \mathrm{kali}$ & 77.440 .000 & 29.951 .880 & 107.391 .880 \\
\hline $\begin{array}{l}\text { Benang } \\
\text { Jahit }\end{array}$ & 346 & $8 \mathrm{kali}$ & 58.080 .000 & 22.271 .910 & 80.351 .910 \\
\hline Additive & 232 & $8 \mathrm{kali}$ & 38.720 .000 & 15.359 .940 & 54.079 .940 \\
\hline Pigmen & 116 & $8 \mathrm{kali}$ & 19.360 .000 & 7.423 .971 & 26.783 .971 \\
\hline
\end{tabular}

Sumber: Data Internal Perusahaan Diolah

Hasil untuk frekuensi pemesanan menggunakan metode Algoritma Wagner Within (AWW) tiap bahan baku sama yakni 8 kali pemesanan per tahun. Dari perhitungan tersebut, dapat disimpulkan bahwa frekuensi pemesanan tiap bahan baku dengan menggunakan metode Algoritma Wagner Within (AWW) lebih kecil daripada konsep aktual yang selama ini diterapkan perusahaan yakni sebesar 12 kali dalam satu tahun.

Tabel 7 berikut merupakan hasil dari Total biaya persediaan tiap bahan baku dengan metode Algoritma Wagner-Within menggunakan software POM for Windows 3.

Tabel 7 Total Biaya Persediaan Tiap Bahan Baku Tahun 2016 Metode Wagner-Within (AWW)

\begin{tabular}{|c|c|c|c|c|c|}
\hline \multicolumn{5}{|c|}{ Total Biaya Persediaan Tiap Bahan Baku (Rp) } & \multirow{2}{*}{$\begin{array}{c}\text { Total Biaya } \\
\text { Persediaan } \\
\text { Bahan Baku } \\
\text { (Rp) }\end{array}$} \\
\hline Bijih Plastik & Inner & $\begin{array}{c}\text { Benang } \\
\text { Jahit }\end{array}$ & Additive & Pig & \\
\hline .417 .213 .000 & 107.391 .900 & 80.351 .910 & 54.079 .940 & 26.783 .971 & 2.685.821.101 \\
\hline
\end{tabular}

Sumber: Data Internal Perusahaan Diolah 
Berikut Tabel 8 adalah hasil perhitungan total biaya persediaan bahan baku tahun 2016 dengan metode Algoritma Wagner-Within menggunakan software POM for Windows 3.

Tabel 8

Hasil Perhitungan Total Biaya Persediaan Bahan Baku Tahun 2016 Metode Wagner-Within (AWW)

\begin{tabular}{c|c|c|}
\hline $\begin{array}{c}\text { Biaya } \\
\text { Pemesanan } \\
(\mathrm{Rp})\end{array}$ & $\begin{array}{c}\text { Biaya } \\
\text { Penyimpanan } \\
(\mathrm{Rp})\end{array}$ & $\begin{array}{c}\text { Total Biaya } \\
\text { Persediaan } \\
(\mathrm{Rp})\end{array}$ \\
\hline 1.936 .000 .000 & 749.821 .101 & 2.685 .821 .101 \\
\hline
\end{tabular}

Sumber: Data Internal Perusahaan Diolah

Total biaya persediaan bahan baku dengan metode Algoritma Wagner-Within (AWW) pada tahun 2016 sebesar Rp 2.685.821.101, dengan biaya pemesanan sebesar Rp 1.936.000.000 dan biaya penyimpanan sebesar Rp 749.821.101.

\subsubsection{Perbandingan Biaya Persediaan Bahan Baku}

Hasil perhitungan total biaya persediaan bahan baku menggunakan metode Algoritma Wagner-Within (AWW) kemudian dibandingkan total biaya persediaan yang dihasilkan oleh konsep aktual yang diterapkan oleh perusahaan. Perbandingan hasil dari metode Algoritma Wagner-Within dan konsep aktual perusahaan dapat dilihat pada Tabel 9 berikut.

Tabel 9 Perbandingan Biaya Persediaan Bahan Baku Tahun 2016

\begin{tabular}{|l|c|c|}
\hline \multirow{2}{*}{\multicolumn{1}{|c|}{ Keterangan }} & \multicolumn{2}{|c|}{ Biaya Persediaan } \\
\cline { 2 - 4 } & $\begin{array}{c}\text { Kondisi Existing } \\
\text { Perusahaan }\end{array}$ & $\begin{array}{c}\text { Metode Algoritma } \\
\text { Wagner-Within } \\
\text { (AWW) }\end{array}$ \\
\hline Frekuensi Pemesanan & $12 \mathrm{kali}$ & $8 \mathrm{kali}$ \\
\hline Biaya Pemesanan & $\mathrm{Rp} \mathrm{2.904.000.000}$ & $\mathrm{Rp} \mathrm{1.936.000.000}$ \\
\hline Biaya Penyimpanan & $\mathrm{Rp} 247.000 .000$ & $\mathrm{Rp} \mathrm{749.821.101}$ \\
\hline Total Biaya Persediaan & $\mathrm{Rp} 3.151 .000 .000$ & $\mathrm{Rp} 2.685 .821 .101$ \\
\hline
\end{tabular}

Sumber: Data Internal Perusahaan Diolah
Berdasarkan hasil perhitungan biaya persediaan bahan baku antara kondisi existing yang selama ini diterapkan perusahaan dengan metode Algoritma Wagner-Within (AWW), terdapat selisih pada masing-masing aspek pada Tabel 9. Frekuensi pemesanan menurut konsep aktual yang selama ini diterapkan perusahaan adalah sebanyak 12 kali, sedangkan berdasarkan metode algoritma Wagner-Within (AWW), frekuensi pemesanan sebanyak 6 kali pemesanan, frekuensi pemesanan ini yang seharusnya dilakukan agar dapat sebisa mungkin menekan biaya pemesanan. Seperti yang sudah dijelaskan sebelumnya, semakin banyak frekuensi pemesanan serta diikuti dengan semakin besarnya jumlah kuantitas pesanan maka biaya pemesanan juga semakin membengkak.

Perbandingan lain yang didapat dari perhitungan-perhitungan di atas adalah biaya pemesanan. Biaya pemesanan rendah didapat dengan menggunakan metode Algoritma Wagner-Within (AWW), sebesar Rp 1.936.000.000. Metode Algoritma Wagner-Within (AWW) itu masih menghasilkan biaya pemesanan lebih rendah dari biaya pemesanan menurut konsep aktual perusahaan yaitu sebesar Rp 2.904.000.000. Biaya pemesanan yang rendah dipengaruhi oleh faktor frekuensi pemesanan, semakin kecil frekuensi memesan bahan baku, semakin kecil pula biaya pemesanan.

Sedangkan untuk biaya penyimpanan, biaya penyimpanan menurut konsep aktual perusahaan masih rendah sebesar Rp 247.000.000 dibandingkan dengan biaya penyimpanan metode Algoritma Wagner-Within (AWW) sebesar Rp 749.821.101. Hal ini dikarenakan metode Algoritma Wagner-Within (AWW) frekuensi pemesanan yang lebih sedikit, tetapi kuantitas bahan yang dipesan semakin banyak sehingga biaya penyimpanan per periode akan semakin besar. 
Dengan menjumlahkan biaya pemesanan dan biaya penyimpanan dari masing-masing metode, dapat disimpulkan bahwa metode Algoritma Wagner-Within (AWW) merupakan metode yang menghasilkan total biaya persediaan bahan baku yang rendah, yaitu sebesar Rp 2.685.821.101, sedangkan menurut konsep aktual perusahaan, total biaya persediaan bahan baku menghasilkan biaya yang tinggi sebesar Rp 3.151.000.000.

Dapat disimpulkan juga bahwa perhitungan metode lot sizing dengan pendekatan metode Algoritma Wagner-Within (AWW) menghasilkan total biaya persediaan bahan baku yang lebih rendah daripada konsep aktual yang selama ini diterapkan oleh perusahaan.

\subsection{Pembahasan}

\subsubsection{Efisiensi Biaya Persediaan Bahan Baku dengan Metode Algoritma Wagner-Within (AWW)}

Dari hasil perhitungan biaya persediaan bahan baku dengan metode Algoritma WagnerWithin (AWW), diketahui bahwa metode lot sizing dengan pendekatan Algoritma Wagner-Within (AWW) dapat meminimalkan biaya persediaan bahan baku dibandingkan dengan konsep aktual yang selama ini diterapkan perusahaan. Tabel 10 menunjukkan presentasi penghematan biaya persediaan bahan baku menggunakan metode Algoritma Wagner-Within (AWW) pada PT X.

Tabel 10 Persentase Penghematan Total Biaya Persediaan Bahan Baku Menggunakan Metode Wagner-Within (AWW) Tahun 2016

\begin{tabular}{|c|c|c|c|c|}
\hline Keterangan & $\begin{array}{c}\text { Kondisi } \\
\text { Existing } \\
\text { Perusahaan } \\
\text { (Rp) }\end{array}$ & $\begin{array}{c}\text { Algoritma } \\
\text { Wagner- } \\
\text { Within (Rp) }\end{array}$ & $\begin{array}{c}\text { Penghematan } \\
\text { (Rp) }\end{array}$ & $\begin{array}{c}\text { Persentase } \\
\text { Penghematan } \\
(\%)\end{array}$ \\
\hline $\begin{array}{c}\text { Total Biaya } \\
\text { Persediaan }\end{array}$ & 3.151 .000 .000 & 2.685 .821 .101 & 465.178 .899 & $14,8 \%$ \\
\hline
\end{tabular}

Sumber: Data Internal Perusahaan Diolah
Berdasarkan hasil perhitungan persentase yang telah dilakukan, maka terdapat perbedaan total biaya persediaan bahan baku antara kondisi existing perusahaan dengan metode Algoritma Wagner-Within (AWW). Di mana adanya penghematan sebesar Rp 465.178.899 atau sekitar 14,8\% jika diterapkannya metode Algoritma Wagner-Within (AWW) dibandingkan dengan kondisi existing yang di terapkan pada PT X.

Pada kondisi existing perusahaan, perusahaan melakukan pemesanan setiap kali adanya produksi yang akan dilakukan atau dalam hal ini adalah 12 kali dalam 1 tahun. Sedangkan dengan menggunakan metode Algoritma WagnerWithin (AWW), pemesanan bahan baku yang dilakukan bervariasi (frekuensi pemesanan) sesuai dengan perhitungan algoritma yang telah dilakukan yakni sebanyak 8 kali dalam 1 tahun.

Metode Algoritma Wagner-Within (AWW) memberikan perencanaan persediaan bahan baku menimbulkan total biaya persediaan yang lebih kecil jika dibandingkan dengan perencanaan persediaan bahan baku yang hanya berdasarkan konsep aktual yang diterapkan perusahaan. Sebaiknya perusahaan mulai menerapkan metode Algoritma Wagner-Within (AWW) agar dapat meminimumkan total biaya persediaan bahan baku yang sangat berpengaruh pada proses bisnis PT X.

\section{KESIMPULAN}

Dari Penelitian yang telah dilakukan pada perencanaan persediaan bahan baku PT X di Tropodo, Sidoarjo, dengan menggunakan metode Algoritma Wagner-Within (AWW) dapat ditarik kesimpulan sebagai berikut.

1. Dengan menggunakan metode Algoritma Wagner-Within (AWW) menjadi lebih efisien dalam hal merencanakan persediaan bahan 
baku di PT X dibandingkan dengan kondisi existing yang diterapkan oleh perusahaan. Berikut ini beberapa rincian kesimpulan hasil metode Algoritma Wagner-Within (AWW).

a. Hal ini ditunjukkan dengan frekuensi pemesanan bahan baku menurut perhitungan metode Algoritma Wagner-Within (AWW), pemesanan bahan baku yang dilakukan sebanyak 8 kali dalam 1 tahun, sedangkan menurut perhitungan kondisi existing perusahaan, pemesanan bahan baku yang dilakukan sebanyak 12 kali dalam 1 tahun. Dengan frekuensi pemesanan yang lebih sedikit (8 kali/tahun) akan menghasilkan biaya pemesanan yang lebih efisien dan optimal dibandingkan frekuensi pemesanan yang lebih banyak (12 kali/tahun).

b. Untuk biaya pemesanan bahan baku dengan menggunakan metode Algoritma Wagner-Within (AWW), sebesar Rp 1.936.000.000. Metode Algoritma Wagner-Within (AWW) tersebut masih menghasilkan biaya pemesanan lebih efisien dan optimal dari biaya pemesanan menurut kondisi existing perusahaan yaitu sebesar Rp 2.904.000.000.

c. Untuk biaya penyimpanan menurut kondisi existing perusahaan masih lebih efisien yakni sebesar Rp 247.000.000 dibandingkan dengan biaya penyimpanan metode Algoritma Wagner-Within (AWW) sebesar Rp 749.821.101. Hal ini dikarenakan metode Algoritma Wagner-Within (AWW) menghasilkan frekuensi pemesanan yang lebih sedikit, tetapi kuantitas bahan baku yang dipesan semakin banyak sehingga biaya penyimpanan akan semakin besar.

d. Untuk total biaya persediaan bahan baku, metode Algoritma Wagner-Within (AWW) merupakan metode yang menghasilkan total biaya persediaan bahan baku yang optimal dan efisien, yaitu Rp 2.685.821.101, sedangkan menurut kondisi existing perusahaan, total biaya persediaan bahan baku menghasilkan biaya yang lebih tinggi yaitu sebesar Rp 3.151.000.000.

\section{DAFTAR REFERENSI}

Assuari, Sofjan. 2004. Manajemen Produksi dan Operasi. Jakarta: FE UI Press.

Bahagia, Nur. 2006. Sistem Inventori. Bandung: Penerbit ITB.

Baroto, Teguh. 2002. Perencanaan dan Pengendalian Produksi. Jakarta: PT Ghalia Indonesia.

Harjanto, Eddy. 1999. Manajemen Produksi dan Operasi. Jakarta: PT Grasindo.

Heizer, Jay \& Barry Render. 2009. Operations Management: Manajemen Operasi. Jakarta: Salemba Empat.

Maulana \& Setyorini. 2012. Perencanaan Kebutuhan Bahan Baku Produk Windlass dengan Menggunakan Metode Lot Sizing pada PT Pindad (Persero). Jurnal Fakultas Komunikasi dan Bisnis. Universitas Telkom.

Pardede, Pontas M. 2005. Manajemen Operasi dan Produksi. Yogyakarta: ANDI.

Rajhans \& Kulkarnia S. 2013. Determination of Optimum Inventory Model for Minimizing Total Inventory Cost. Jurnal Internasional. Nirma University International Conference on Engineering.

Rangkuti, Freddy. 2004. Manajemen Persediaan: Aplikasi di Bidang Bisnis. Jakarta: PT Raja Grafindo Persada.

Rasjidin, dkk. 2007. Penentuan Kombinasi Metode Lot Sizing berbagai Level pada Struktur Produk Spion 7024 untuk Meminimalisasi Biaya Persediaan di PT Cipta Kreasi Prima 
Muda. Jurnal Inovasi. Teknik Industri, Universitas Indonesia Esa Unggul.

Sugiyono. 2010. Metode Penelitian Bisnis (Pendekatan Kuantitatif, Kualitatif, dan RひD). Bandung: Alfabeta.

Sumayang, L. 2003. Dasar-Dasar Manajemen Produksi dan Operasi. Jakarta: Salemba Empat.

Tampubolon, Manahan P. 2004. Manajemen Operasional (Operations Management). Jakarta: Ghalia Indonesia.
Wagner, Harvey M. \& Whitin, Thomson M. 2004. Dynamic Version of the Economic Lot Size Model. Jurnal Internasional. Management Science, Vol.50(12) Supplement, pp.1770-1774.

Yamit, Zulian. 2005. Manajemen Persediaan. Jakarta: Ekonisia. 
Business and Finance Journal, Volume 3, No. 1, March 2018 